\title{
Conversion reactions for sodium-ion batteries $\dagger$
}

\author{
Cite this: Phys. Chem. Chem. Phys., 2013, Franziska Klein, Birte Jache, Amrtha Bhide and Philipp Adelhelm*
}

15, 15876

Received 20th May 2013,

Accepted 27th June 2013

DOI: $10.1039 / \mathrm{c} 3 \mathrm{cp} 52125 \mathrm{~g}$

www.rsc.org/pccp

\begin{abstract}
Research on sodium-ion batteries has recently been rediscovered and is currently mainly focused on finding suitable electrode materials that enable cell reactions of high energy densities combined with low cost. Naturally, an assessment of potential electrode materials requires a rational comparison with the analogue reaction in lithium-ion batteries. In this paper, we systematically discuss the broad range of different conversion reactions for sodium-ion batteries based on their basic thermodynamic properties and compare them with their lithium analogues. Capacities, voltages, energy densities and volume expansions are summarized to sketch out the scope for future studies in this research field. We show that for a given conversion electrode material, replacing lithium by sodium leads to a constant shift in cell potential $\Delta E_{(\mathrm{Li}-\mathrm{Na})}^{\mathrm{a}}$ depending on the material class. For chlorides $\Delta E_{(\mathrm{Li}-\mathrm{Na})}^{\circ}$ equals nearly zero. The theoretical energy densities of conversion reactions of sodium with fluorides or chlorides as positive electrode materials typically reach values between $700 \mathrm{~W} \mathrm{~h} \mathrm{~kg}^{-1}$ and $1000 \mathrm{~W} \mathrm{~h} \mathrm{~kg}^{-1}$. Next to the thermodynamic assessment, results on several conversion reactions between copper compounds (CuS, $\mathrm{CuO}, \mathrm{CuCl}, \mathrm{CuCl}_{2}$ ) and sodium are being discussed. Reactions with $\mathrm{CuS}$ and $\mathrm{CuO}$ were chosen because these compounds are frequently studied for conversion reactions with lithium. Chlorides are interesting because of $\Delta E_{(\mathrm{Li}-\mathrm{Na})}^{\mathrm{O}} \approx 0 \mathrm{~V}$. As a result of chloride solubility in the electrolyte, the conversion process proceeds at defined potentials under rather small kinetic limitations.
\end{abstract}

\section{Introduction}

The development of safe and low cost electrochemical energy storage devices with high energy densities is one of the key challenges for current battery research. ${ }^{1,2}$ Current lithium-ion battery technology is largely based on the reversible formation of intercalation compounds with layered (e.g. $\mathrm{LiCoO}_{2}$, graphite) or tunneled (e.g. $\mathrm{LiMn}_{2} \mathrm{O}_{4}, \mathrm{LiFePO}_{4}$ ) structures. ${ }^{3-6}$ Despite the commercial success, one disadvantage is the limited capacity of these compounds, with values below $200 \mathrm{~mA} \mathrm{~h} \mathrm{~g}^{-1}$ for transition metal oxides and phosphates and a capacity of $372 \mathrm{~mA} \mathrm{~h} \mathrm{~g}{ }^{-1}$ for graphite. In order to further improve the energy densities of batteries, either the voltage of the cell reaction and/or the capacity of the electrode materials have to be increased. Higher capacities can be achieved by compounds that undergo so-called conversion reactions with lithium. The general reaction can be written as

$$
\mathrm{M}_{a} \mathrm{X}_{b}+(b c) \mathrm{Li} \rightleftarrows a \mathrm{M}+b \mathrm{Li}_{c} \mathrm{X} \quad \Delta_{\mathrm{r}} G=\Delta_{\mathrm{r}} H-T \Delta_{\mathrm{r}} S
$$

with $\mathrm{M}$ being a transition metal and $\mathrm{X}$ a non-metal (i.e. $\mathrm{F}, \mathrm{O}, \mathrm{P}$, $\mathrm{N}, \mathrm{S}, \mathrm{H}, \ldots)$.

Institute of Physical Chemistry, Justus-Liebig-University Giessen, Heinrich-Buff-Ring 58, 35392 Giessen, Germany. E-mail: philipp.adelhelm@uni-giessen.de

† Electronic supplementary information (ESI) available. See DOI: 10.1039/ c3cp52125g
The full reduction of the transition metal during discharge generally leads to higher capacities compared to intercalation compounds. An illustrative example is $\mathrm{Co}_{3} \mathrm{O}_{4}\left(\mathrm{Co}^{\mathrm{II}} \mathrm{Co}_{2}^{\mathrm{III}} \mathrm{O}_{4}\right)$, where full reduction of the $\mathrm{Co}^{2+} / \mathrm{Co}^{3+}$ cations by lithium to form Co and $\mathrm{Li}_{2} \mathrm{O}$ corresponds to a capacity of $890.4 \mathrm{~mA} \mathrm{~h} \mathrm{~g}\left(\mathrm{Co}_{3} \mathrm{O}_{4}\right)^{-1}$. In comparison, reducing $\mathrm{Co}^{4+}$ to $\mathrm{Co}^{3+}$ in the classical $\mathrm{LiCoO}_{2}$ intercalation compound leads to a capacity of $273.8 \mathrm{~mA} \mathrm{~h} \mathrm{~g}\left(\mathrm{LiCoO}_{2}\right)^{-1}$ (roughly half of this value is reached in practice, as only about 0.5 lithium atoms per formula can be reversibly intercalated).

The cell chemistry of conversion reactions has been studied already for many years and reports date back to the 70s and 80s. Usually, the cells operated at high temperature (e.g. $\mathrm{Fe}_{2} \mathrm{O}_{3}{ }^{7}$ and $\mathrm{FeS}_{2}{ }^{8}$ ) using molten salts as electrolytes but also some studies at room temperature have been reported on $\mathrm{CuO}, \mathrm{Co}_{3} \mathrm{O}_{4}{ }^{9-13}$ and $\mathrm{CuS}^{14}$ for example. Research on conversion reactions strongly evolved since the work reported by Idota et al. ${ }^{15}$ on tin based composite oxides and Poizot et al. ${ }^{16}$ on several binary transition metal oxides, who also found a remarkable reversibility of the cell reaction at room temperature. Since then a large variety of compounds has been studied and progress and challenges have been recently well summarized in the literature. ${ }^{17,18}$

A logical way to study the properties of conversion reactions is to systematically vary either $\mathrm{M}$ or $\mathrm{X}$ for a given compound. It is generally found that the voltages $v s . \mathrm{Li} / \mathrm{Li}^{+}$increase with the 
ionicity of the bond, i.e. fluorides exhibit the highest voltages of around $3 \mathrm{~V}$ for a given cell reaction. Oxides, sulfides and phosphides show intermediate potentials between 1 and $2 \mathrm{~V}$, and $\mathrm{MgH}_{2}$ (most covalent bond) exhibits the lowest voltage of $0.5 \mathrm{~V}^{19}$ Similarly, the cell potential for compounds with the same stoichiometry increases with the atomic number of $\mathrm{M}^{20}$ Hence the electrode potential can be conveniently tuned by combining different $\mathrm{M}$ and $\mathrm{X}$ species.

On the other hand, conversion reactions generally suffer from large irreversible capacities during the first cycle (typically coulombic efficiencies are below 75\%) and, even more important, poor energy efficiency due to large polarization effects. Overpotentials are intrinsic to conversion reactions and their magnitude increases with the ionicity of the MX bond. Hence a high electrode potential is usually correlated with large polarization effects. A comparison by Oumellal et al. for different cobalt compounds $\mathrm{Co}_{a} \mathrm{X}_{b}$ and $\mathrm{MgH}_{2}$ showed that the combined overpotentials for discharge and charge decrease in the order $\mathrm{X}=\mathrm{F}(\approx 1.1 \mathrm{~V})>\mathrm{O}$ $(\approx 0.9 \mathrm{~V})>\mathrm{S}(\approx 0.7 \mathrm{~V})>\mathrm{N}(\approx 0.6 \mathrm{~V})>\mathrm{P}(\approx 0.4 \mathrm{~V})>\mathrm{H}(\approx 0.25 \mathrm{~V}) .{ }^{19}$ The at first unexpected reactivity of non-conductive species such as $\mathrm{Li}_{2} \mathrm{O}$ and $\mathrm{LiF}$ is rooted in the formation of a nanoscopic structure during the first discharge process. This structure consists of metal nanoparticles of a few nanometers in size which are embedded in a $\mathrm{Li}_{c} \mathrm{X}$ matrix. ${ }^{21-23}$ This way, diffusion distances remain small enough to allow a reversible cell reaction during the subsequent cycles. Recently, the formation of the nanoscopic structure has been followed by in situ TEM for the Fe-LiF system. ${ }^{24}$

Another peculiarity of conversion reactions is that the experimentally determined capacities often exceed the theoretical values. Additional capacitive (non-faradaic) charge storage at the interfaces of the nanoscopic structure ${ }^{25-27}$ and electrolyte decomposition ${ }^{28-33}$ has been discussed. Data on the cycle life of conversion electrodes widely scatters in literature and the experimental results heavily depend on the type of material investigated. But also other parameters such as materials morphology, electrode and cell preparation and the applied cycling conditions have a major impact. Only a few examples exist where sufficient capacity retention is maintained for 100 or more cycles. ${ }^{18}$

Exchanging lithium by sodium would be another possibility to alter the cell reaction, but only a very few experimental studies have been reported. The few compounds studied include $\mathrm{CuO},{ }^{10} \mathrm{Cu}_{2} \mathrm{~S},{ }^{34} \mathrm{FeS}_{2},{ }^{35} \mathrm{Fe}_{3} \mathrm{O}_{4},{ }^{72} \mathrm{Cu}_{2} \mathrm{Se},{ }^{73} \mathrm{Ni}_{3} \mathrm{~N},{ }^{50}$ $\mathrm{NiCo}_{2} \mathrm{O}_{4},{ }^{36}$ thin film $\mathrm{Sb}_{2} \mathrm{O}_{4}{ }^{37}$ and $\mathrm{Ni}_{3} \mathrm{~S}_{2}{ }^{38}$ Experimental evidence for a successful conversion reaction was, however, only achieved for the last six of these compounds. Clearly, a more comprehensive analysis of sodium based conversion reactions is worthwhile, also because the natural abundance of sodium recently led to a renewed interest in sodium-ion batteries ${ }^{39-42}$ and the sodium analogues of next generation systems, i.e. Na/air ${ }^{43-45}$ and low temperature $\mathrm{Na} / \mathrm{S}^{46-48}$

In order to understand whether conversion reactions based on sodium are rational, we firstly discuss systematically the basic thermodynamic properties (cell voltages, capacities, energy densities) of possible cell reactions and compare the results with the analogue lithium based systems. Secondly, we will discuss the expected volume expansions of the electrode during cell reaction. At last, we will discuss the primary electrochemical properties of the sodium conversion reactions with $\mathrm{CuO}, \mathrm{CuS}, \mathrm{CuCl}_{2}$ and $\mathrm{CuCl}$ as examples.

\section{Thermodynamic aspects - Gibbs energy and EMF}

\subsection{Effect of replacing lithium by sodium on the cell potential of conversion reactions}

Whether any electrode reaction can be used in practice as a positive or a negative electrode in an electrochemical cell depends first of all on the thermodynamic properties. Compared to intercalation compounds, a thermodynamic treatment for conversion systems is straightforward. Thermodynamic data for the reactants and products are usually known and the corresponding cell potentials, capacities and energy densities can be easily calculated as long as pure bulk phases and full conversion are assumed. It is important to note that conversion reactions can proceed via intermediate steps, include amorphous phases and feature large interfacial areas due to the nanoscopic structure. Intermediate steps do not affect the capacity, the average voltage and hence the energy density of the overall cell reaction, but the latter factors can lead to minor deviations from the thermodynamic properties of the bulk phases. Nevertheless, calculating the thermodynamic properties based on pure bulk phases assuming complete conversion is useful in order to compare the principal properties and differences between sodium and lithium based conversion reactions. Further, a broad analysis is essential to assess the thermodynamical limits of sodium based conversion reactions and will provide a guideline on which compounds could be potentially used as negative and positive active electrode materials.

In the following, we discuss the basic thermodynamic aspects of lithium and sodium based conversion reactions. We start with the exemplary calculation of the electromotive force $E^{\mathrm{O}}$ (cell potential) for the conversion reaction of $\mathrm{CoO}$ with lithium and sodium, respectively.

The ideal and direct reaction between $\mathrm{CoO}$ and lithium or sodium, respectively, can be written as

$$
\mathrm{CoO}+2 \mathrm{~A} \rightleftarrows \mathrm{Co}+\mathrm{A}_{2} \mathrm{O}
$$

with A being the alkali metal.

The standard reaction enthalpy $\Delta_{\mathrm{r}} H^{\mathrm{o}}$, entropy $\Delta_{\mathrm{r}} S^{\mathrm{O}}$ and Gibbs energy $\Delta_{\mathrm{r}} G^{\circ}$ for both reactions at $T=298 \mathrm{~K}$ are summarized in Table 1 . The standard cell potential $E^{\mathrm{o}}$ can be calculated using

$$
E^{\circ}=-\frac{\Delta_{\mathrm{r}} G^{\circ}}{z \cdot F}
$$

Therefore, the difference in cell potential between the lithium and sodium based conversion reaction with $\mathrm{CoO}$ is $\Delta E_{(\mathrm{Li}-\mathrm{Na})}^{\mathrm{O}}=E_{(\mathrm{Li})}^{\mathrm{O}}-E_{(\mathrm{Na})}^{\mathrm{O}}=1.80-0.84 \mathrm{~V}=0.96 \mathrm{~V}$.

The same difference in cell potential is found for any other conversion reaction based on a transition metal oxide $\mathrm{M}_{a} \mathrm{O}_{b}$. This can be easily understood when comparing the 
Table 1 Thermodynamic data for the conversion reaction of $\mathrm{CoO}$ with $\mathrm{Li}$ and $\mathrm{Na}$ $(T=298 \mathrm{~K})$

\begin{tabular}{lllll}
\hline & $\begin{array}{l}\Delta_{\mathrm{r}} H^{\mathrm{o}} / \\
\mathrm{kJ} \mathrm{mol}^{-1}\end{array}$ & $\begin{array}{l}\Delta_{\mathrm{r}} S^{\mathrm{o}} / \\
\mathrm{J} \mathrm{mol}^{-1} \mathrm{~K}^{-1}\end{array}$ & $\begin{array}{l}\Delta_{\mathrm{r}} G^{\mathrm{o}} / \\
\mathrm{kJ} \mathrm{mol}\end{array}$ & $E^{\mathrm{o}} / \mathrm{V}$ \\
\hline $\mathrm{CoO}+2 \mathrm{Li} \rightleftarrows \mathrm{Co}+\mathrm{Li}_{2} \mathrm{O}$ & -359.94 & -43.56 & -346.95 & 1.80 \\
$\mathrm{CoO}+2 \mathrm{Na} \rightleftarrows \mathrm{Co}+\mathrm{Na}_{2} \mathrm{O}$ & -177.16 & -50.49 & -162.10 & 0.84 \\
\hline
\end{tabular}

generalized formulas for sodium and lithium based conversion reactions:

$$
\begin{aligned}
\mathrm{M}_{a} \mathrm{X}_{b}+(b c) \cdot \mathrm{Na} & \rightleftarrows a \mathrm{M}+b \mathrm{Na}_{c} \mathrm{X} \\
\mathrm{M}_{a} \mathrm{X}_{b}+(b c) \cdot \mathrm{Li} & \rightleftarrows a \mathrm{M}+b \mathrm{Li}_{c} \mathrm{X}
\end{aligned}
$$

Subtracting eqn (I) from eqn (II) leads to

$$
\begin{aligned}
& \mathrm{M}_{a} \mathrm{X}_{b}+(b \cdot c) \cdot \mathrm{Li}+a \cdot \mathrm{M}+b \cdot \mathrm{Na}_{c} \mathrm{X} \\
& \quad \rightleftarrows a \cdot \mathrm{M}+b \cdot \mathrm{Li}_{c} \mathrm{X}+\mathrm{M}_{a} \mathrm{X}_{b}+(b \cdot c) \cdot \mathrm{Na}
\end{aligned}
$$

and hence

$$
c \mathrm{Li}+\mathrm{Na}_{c} \mathrm{X} \rightleftarrows \mathrm{Li}_{c} \mathrm{X}+c \mathrm{Na}
$$

This means that the potential difference of a lithium and sodium based conversion reaction against the same $\mathrm{M}_{a} \mathrm{X}_{b}$ compound solely depends on the nonmetal X.

For oxides and for $c=2$, eqn (IV) is then written as

$$
2 \mathrm{Li}+\mathrm{Na}_{2} \mathrm{O} \rightleftarrows \mathrm{Li}_{2} \mathrm{O}+2 \mathrm{Na}
$$

For this reaction the standard Gibbs energy is $\Delta_{\mathrm{r}} G^{\mathrm{o}}=$ $-184.85 \mathrm{~kJ} \mathrm{~mol}^{-1}$. The corresponding cell potential is $+0.96 \mathrm{~V}$, which equals the aforementioned difference between the conversion reaction of $\mathrm{CoO}$ with $\mathrm{Na}$ and $\mathrm{Li}$, respectively.
The same calculation can be done for other conversion reactions with $\mathrm{X}=\mathrm{H}, \mathrm{O}, \mathrm{S}, \mathrm{F}, \mathrm{Cl}, \mathrm{Br}$, and $\mathrm{I}$, for example (Fig. 1a). It can be seen that for hydrides, oxides, sulfides and fluorides, the cell potentials shift to lower values when lithium is substituted by sodium in conversion reactions. For chlorides, the cell potentials are nearly the same, and for iodides and bromides, sodium conversion reactions show even higher cell voltages compared to the corresponding reaction with lithium. This is remarkable, as sodium based cells are usually intuitively considered to provide a lower cell voltage compared to their lithium analogues.

The origin for this finding can be well explained by considering the differences in lattice energies between $\mathrm{Na}_{c} \mathrm{X}$ and $\mathrm{Li}_{c} \mathrm{X}$ compounds and the corresponding Born-Haber cycles. At room temperature, the value for $\Delta_{\mathrm{r}} G^{\mathrm{o}}$ is dominated by the reaction enthalpy $\Delta_{\mathrm{r}} H^{\mathrm{O}}$ (the term $T \Delta_{\mathrm{r}} S$ is comparably small and the entropy difference between analogue lithium and sodium compounds is negligible). $\Delta_{\mathrm{r}} H^{\circ}$ can be determined from the lattice enthalpy $\Delta_{\text {lattice }} H^{\circ}$ considering the Born-Haber cycle (Fig. 1b). For $\mathrm{NaF}$ as an example, one finds

$$
\begin{aligned}
\Delta_{\mathrm{r}} H= & \Delta_{\mathrm{sub}} H^{\mathrm{o}}(\mathrm{Na}(\mathrm{s}) / \mathrm{Na})+\Delta_{\text {ion }} H^{\mathrm{o}}\left(\mathrm{Na} / \mathrm{Na}^{+}\right)+\Delta_{\text {bond }} H^{\mathrm{o}}\left(\mathrm{F}_{2} / 2 \mathrm{~F}\right) \\
& +\Delta_{\mathrm{EA}} H^{\mathrm{o}}\left(\mathrm{F} / \mathrm{F}^{-}\right)-\Delta_{\text {lattice }} H^{\mathrm{o}}(\mathrm{NaF}(\mathrm{s}))
\end{aligned}
$$

The indices sub, ion, bond, and EA indicate sublimation, ionization, bonding and electron affinity. Subtracting this from the corresponding values for LiF, one obtains the difference in reaction enthalpies $\Delta \Delta_{\mathrm{r}} H_{(\mathrm{Li}-\mathrm{Na})}^{\mathrm{o}}$

$$
\begin{aligned}
\Delta \Delta_{\mathrm{r}} H_{(\mathrm{Li}-\mathrm{Na})}^{\mathrm{o}}= & \Delta_{\mathrm{sub}} H^{\mathrm{o}}(\mathrm{Li})+\Delta_{\mathrm{ion}} H^{\mathrm{o}}\left(\mathrm{Li} / \mathrm{Li}^{+}\right)-\Delta_{\text {sub }} H^{\mathrm{o}}(\mathrm{Na}) \\
& -\Delta_{\text {ion }} H^{\mathrm{o}}\left(\mathrm{Na} / \mathrm{Na}^{+}\right)-\Delta_{\text {lattice }} H^{\mathrm{o}}(\mathrm{LiF})+\Delta_{\text {lattice }} H^{\mathrm{o}}(\mathrm{NaF})
\end{aligned}
$$

or simplified

$$
\Delta \Delta_{\mathrm{r}} H_{(\mathrm{Li}-\mathrm{Na})}^{\mathrm{o}}=\Delta_{\mathrm{sub}} H_{(\mathrm{Li}-\mathrm{Na})}^{\mathrm{o}}+\Delta_{\mathrm{ion}} H_{(\mathrm{Li}-\mathrm{Na})}^{\mathrm{o}}-\Delta_{\text {lattice }} H_{(\mathrm{Li}-\mathrm{Na})}^{\mathrm{o}}
$$
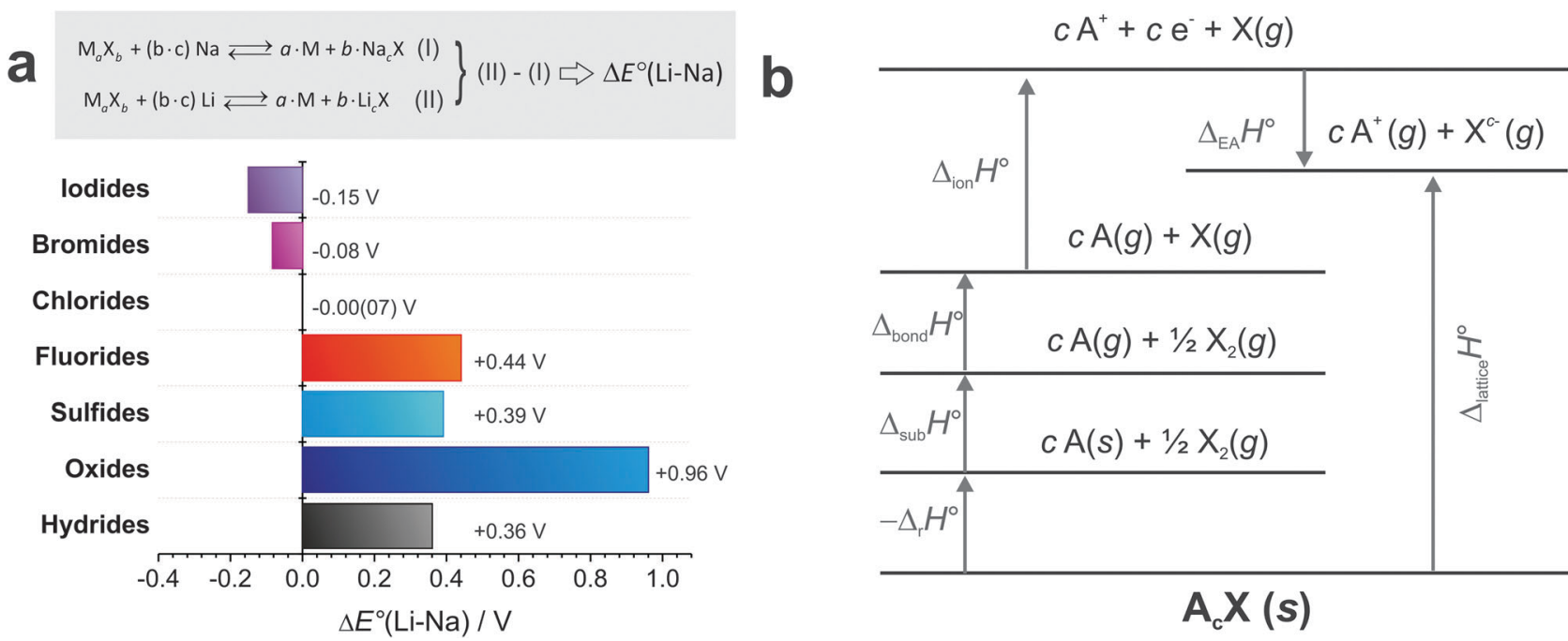

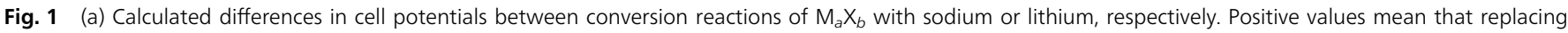

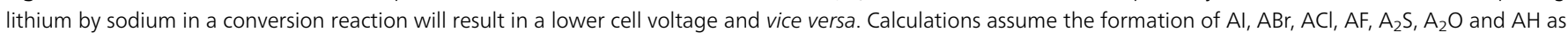

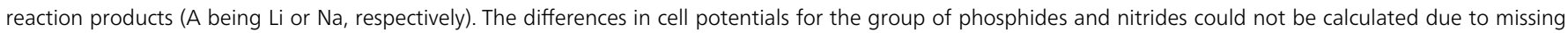

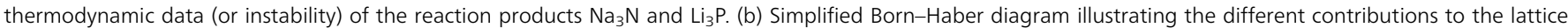

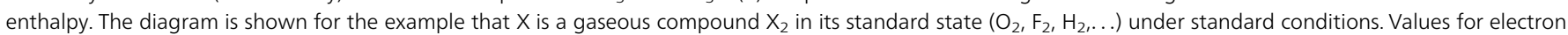

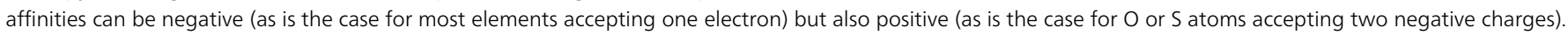


Table 2 Lattice energies (per mol alkali metal) ${ }^{74}$ and differences in cell potential

\begin{tabular}{lcccl}
\hline & $\begin{array}{l}\Delta_{\text {lattice } H^{\mathrm{o}}\left(\mathrm{Li}_{c} \mathrm{X}\right) /} \\
\mathrm{kJ} \mathrm{mol}^{-1}\end{array}$ & $\begin{array}{l}\Delta_{\text {lattice } H^{\mathrm{o}}\left(\mathrm{Na}_{c} \mathrm{X}\right) /} \\
\mathrm{kJ} \mathrm{mol}^{-1}\end{array}$ & $\begin{array}{l}\Delta_{\text {lattice } H_{(\mathrm{Li}-\mathrm{Na})}^{\mathrm{o}} /} \\
\mathrm{kJ} \mathrm{mol}^{-1}\end{array}$ & $\begin{array}{l}\Delta E_{(\mathrm{Li}-\mathrm{Na})}^{\mathrm{o}} / \\
\mathrm{V}\end{array}$ \\
\hline $\mathrm{LiI} / \mathrm{NaI}$ & 764 & 705 & 59 & -0.15 \\
$\mathrm{LiBr} / \mathrm{NaBr}$ & 820 & 754 & 66 & -0.08 \\
$\mathrm{LiCl} / \mathrm{NaCl}$ & 864 & 790 & 74 & $-0.00(07)$ \\
$\mathrm{LiF} / \mathrm{NaF}$ & 1049 & 930 & 119 & +0.44 \\
$\mathrm{Li} 2 \mathrm{~S} / \mathrm{Na}_{2} \mathrm{~S}$ & $(1236)$ & $(1101)$ & $(135)$ & +0.39 \\
$\mathrm{Li} 2 \mathrm{O} / \mathrm{Na}_{2} \mathrm{O}$ & 1407 & 1239 & 168 & +0.96 \\
$\mathrm{LiH} / \mathrm{NaH}$ & 918 & 807 & 111 & +0.36 \\
\hline
\end{tabular}

Values of $\Delta_{\text {sub }} H^{\circ}$ and $\Delta_{\text {ion }} H^{\circ}$ are higher for lithium (159.3 $\left.\mathrm{kJ} \mathrm{mol}^{-1}, 520.2 \mathrm{~kJ} \mathrm{~mol}^{-1}\right)$ than for sodium $\left(107.5 \mathrm{~kJ} \mathrm{~mol}^{-1}\right.$, $495.8 \mathrm{~kJ} \mathrm{~mol}^{-1}$ ) so that the equation can be written as

$$
\Delta \Delta_{\mathrm{r}} H_{(\mathrm{Li}-\mathrm{Na})}^{\mathrm{o}}=76.2 \mathrm{~kJ} \mathrm{~mol}^{-1}-\Delta_{\text {lattice }} H_{(\mathrm{Li}-\mathrm{Na})}^{\mathrm{o}}
$$

This means that for values of $\Delta_{\text {lattice }} H_{(\mathrm{Li}-\mathrm{Na})}^{\mathrm{o}}$ larger than $76.2 \mathrm{~kJ} \mathrm{~mol}^{-1}$, the cell potential of the conversion reaction with lithium is higher compared to sodium. Below this value, the sodium based conversion reaction shows a higher cell potential (Table 2). In the case of chlorides, the difference in lattice enthalpy is fully compensated, hence explaining the nearly identical cell potentials of conversion reactions with both alkali metals. Also, a linear relationship between $\Delta_{\text {lattice }} H_{(\mathrm{Li}-\mathrm{Na})}^{\mathrm{a}}$ and $\Delta E_{(\mathrm{Li}-\mathrm{Na})}^{\mathrm{O}}$ is found (Fig. $\mathrm{S} 1$, ESI $\dagger$ ).

In conclusion, the theoretical cell potential of sodium based conversion systems can be, depending on the non-metal species, lower, almost identical or higher compared to the analogue lithium based systems.

\subsection{Specific capacities, cell potentials and energy densities}

From the large number of different conversion compounds that have been studied in the last years, the following compounds appear to be the best examined ones for conversion reaction with lithium ${ }^{18}$ (the ones that have also been studied in sodium

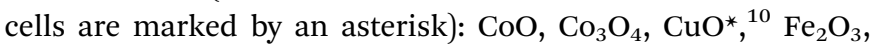
$\mathrm{FeO}, \mathrm{RuO}_{2}$ (oxides); CoS, CuS, $\mathrm{Cu}_{2} \mathrm{~S}^{*},{ }^{34} \mathrm{FeS}^{*},{ }^{35} \mathrm{Ni}_{3} \mathrm{~S}_{2}{ }^{* 38,49}$ (sulphides); $\mathrm{CoN}, \mathrm{Cu}_{3} \mathrm{~N}, \mathrm{Ni}_{3} \mathrm{~N}^{* 50}$ (nitrides); $\mathrm{NiP}_{2}, \mathrm{Cu}_{3} \mathrm{P}$ (phosphides); $\mathrm{CuF}_{2}, \mathrm{FeF}_{2}, \mathrm{TiF}_{3}$ (fluorides); $\mathrm{CuCl}_{2}$ (chlorides); $\mathrm{MgH}_{2}$ (hydride); $\mathrm{NiCo}_{2} \mathrm{O}_{4}{ }^{*} \cdot{ }^{36}$

Based on these compounds some systematic series on (i) various copper-nonmetal compounds, (ii) chalcogenides and (iii) halides will be more closely discussed in terms of their conversion reaction with sodium and lithium. A more comprehensive summary can be found in the ESI $\dagger$ (Table S1). Table 3 shows the standard Gibbs free energy, the cell potential, the theoretical specific charge capacity (theoretical capacity) and the theoretical specific energy (theoretical energy density) for the conversion reaction for the above-mentioned systems.

From the tabulated data, general trends can be drawn most easily from graphical illustrations. We note that for the purpose of demonstrating tendencies within the periodic table, we also include substances such as $\mathrm{TiCl}_{4}$ or $\mathrm{CuH}$, for example, which cannot be used in practice. Values for reactions involving $\mathrm{Na}_{3} \mathrm{~N}$ and $\mathrm{Li}_{3} \mathrm{P}$ are not given due to the lack of thermodynamic data.
Table 3 Thermodynamic data for frequently studied lithium based conversion reactions in comparison to the analogue sodium based systems. The theoretical capacity $q\left[\mathrm{~A} \mathrm{~h} \mathrm{~kg}{ }^{-1}\right]$ is calculated using $q_{\mathrm{th}}=(z \mathrm{~F}) /(3.6 \mathrm{M})$, with $z$ being the number of transferred electrons, $F$ the Faraday constant and $M$ the molar mass of the compound before conversion. The theoretical energy density $W_{\text {th }}$ is calculated using $W_{\text {th }}=E^{\circ} q$. Values for reactions involving $\mathrm{Na}_{3} \mathrm{~N}$ and $\mathrm{Li}_{3} P$ are not given due to the lack of thermodynamic data (or instability)

\begin{tabular}{|c|c|c|c|c|c|c|c|c|}
\hline \multirow[b]{2}{*}{ Compound } & \multirow{2}{*}{\multicolumn{2}{|c|}{$z \stackrel{q_{\mathrm{th}} /}{\mathrm{Ah} \mathrm{kg}^{-1}}$}} & \multicolumn{2}{|c|}{$\Delta_{\mathrm{r}} G^{\mathrm{o}} / \mathrm{kJ} \mathrm{mol}^{-1}$} & \multicolumn{2}{|l|}{$E^{\mathrm{o}} / \mathrm{V}$} & \multicolumn{2}{|c|}{$\begin{array}{l}w_{\text {th }} / \\
\text { W h kg } \\
-1\end{array}$} \\
\hline & & & $\mathrm{Na}$ & $\mathrm{Li}$ & $\begin{array}{l}\text { vs. } \\
\mathrm{Na} / \mathrm{Na}^{+}\end{array}$ & $\begin{array}{l}v s . \\
\mathrm{Li} / \mathrm{Li}^{+}\end{array}$ & $\mathrm{Na}$ & $\mathrm{Li}$ \\
\hline $\mathrm{MgH}_{2}$ & 2 & 2036 & -30.72 & -100.37 & 0.16 & 0.52 & 118 & 695 \\
\hline $\mathrm{Co}_{3} \mathrm{~N}$ & 3 & 421 & $\mathrm{n} / \mathrm{a}$ & -163.00 & $\mathrm{n} / \mathrm{a}$ & 0.56 & $\mathrm{n} / \mathrm{a}$ & 214 \\
\hline $\mathrm{Ni}_{3} \mathrm{~N}$ & 3 & 423 & $\mathrm{n} / \mathrm{a}$ & -155.47 & $\mathrm{n} / \mathrm{a}$ & 0.54 & $\mathrm{n} / \mathrm{a}$ & 205 \\
\hline $\mathrm{NiP}_{2}$ & 6 & 1333 & -252.88 & $\mathrm{n} / \mathrm{a}$ & 0.44 & $\mathrm{n} / \mathrm{a}$ & 272 & $\mathrm{n} / \mathrm{a}$ \\
\hline $\mathrm{Cu}_{3} \mathrm{P}$ & 3 & 363 & -14.99 & $\mathrm{n} / \mathrm{a}$ & 0.05 & $\mathrm{n} / \mathrm{a}$ & 14 & $\mathrm{n} / \mathrm{a}$ \\
\hline $\mathrm{FeO}$ & 2 & 746 & -125.72 & -310.56 & 0.65 & 1.61 & 296 & 1006 \\
\hline $\mathrm{Fe}_{2} \mathrm{O}_{3}$ & 6 & 1007 & -384.66 & -939.20 & 0.66 & 1.62 & 359 & 1296 \\
\hline $\mathrm{CoO}$ & 2 & 715 & -162.10 & -346.95 & 0.84 & 1.80 & 372 & 1085 \\
\hline $\mathrm{Co}_{3} \mathrm{O}_{4}$ & 8 & 891 & -710.30 & -1449.68 & 0.92 & 1.88 & 465 & 1359 \\
\hline $\mathrm{CuO}$ & 2 & 674 & -246.71 & -431.55 & 1.28 & 2.24 & 546 & 1283 \\
\hline $\mathrm{RuO}_{2}$ & 4 & 806 & -499.94 & -869.64 & 1.30 & 2.25 & 617 & 1502 \\
\hline FeS & 2 & 610 & -257.48 & -332.28 & 1.33 & 1.72 & 534 & 907 \\
\hline CoS & 2 & 589 & -261.00 & -335.80 & 1.35 & 1.74 & 529 & 889 \\
\hline $\mathrm{Ni}_{3} \mathrm{~S}_{2}$ & 4 & 446 & -505.20 & -654.80 & 1.31 & 1.70 & 422 & 679 \\
\hline $\mathrm{CuS}$ & 2 & 561 & -304.02 & -378.82 & 1.58 & 1.96 & 596 & 961 \\
\hline $\mathrm{TiF}_{3}$ & 3 & 767 & -277.17 & -404.09 & 0.96 & 1.40 & 443 & 893 \\
\hline $\mathrm{FeF}_{2}$ & 2 & 571 & -424.06 & -508.68 & 2.20 & 2.64 & 842 & 1312 \\
\hline $\mathrm{CuF}_{2}$ & 2 & 528 & -597.13 & -681.74 & 3.09 & 3.53 & 1124 & 1641 \\
\hline $\mathrm{CuCl}_{2}$ & 2 & 399 & -593.22 & -593.09 & 3.07 & 3.07 & 913 & 1111 \\
\hline
\end{tabular}

Fig. 2a shows the change in cell potential for a given transition metal, here $\mathrm{Cu}$ as an example, with the type of anion. It is known from lithium based conversion reactions that the potential shifts towards more positive values with increasing bond ionicity, i.e. increasing values for the difference in the electronegativity values, $\Delta \mathrm{EN}$. This means that conversion reactions with halogens show high potentials (potential cathode electrode materials), chalcogens intermediate potentials and nitrides, phosphides and hydrides low potentials (potential anode electrode materials). As $\Delta E_{(\mathrm{Li}-\mathrm{Na})}^{\mathrm{i}}$ is the same for the different classes of compounds, the same trend is found for sodium based conversion reactions. A similar relation can be found when varying the transition metal for a given anion species (here $\mathrm{O}$ and $\mathrm{S}$ as examples); however the effect on the cell potential is smaller (Fig. 2b). For oxides and sulfides, the cell potentials typically range between $0.1-1.3 \mathrm{~V}$ and $0.7-1.6 \mathrm{~V}$, respectively, so most of them can be considered potential anode materials in sodium-ion batteries. It can also be seen that the cell potential rises with the increasing oxidation state for a given transition metal. Some oxides such as $\mathrm{TiO}_{2}$ or $\mathrm{Al}_{2} \mathrm{O}_{3}$ are too stable and cannot undergo a conversion reaction with sodium as a result of a positive Gibbs free energy (i.e. negative cell potential).

The theoretical specific capacities for several oxides and sulfides are shown in Fig. 2c. Naturally, the capacities increase with the oxidation state of the transition metal $\left(715 \mathrm{~mA} \mathrm{~h} \mathrm{~g}^{-1}\right.$ for $\mathrm{CoO}$ and $890 \mathrm{~mA} \mathrm{~h} \mathrm{~g}^{-1}$ for $\mathrm{Co}_{3} \mathrm{O}_{4}$, for example) and decrease with the atomic number of the transition metal. So the possibly achievable capacities for oxides and sulfides are somewhere between around $300 \mathrm{~mA} \mathrm{~h} \mathrm{~g} \mathrm{~g}^{-1}$ and $1000 \mathrm{~mA} \mathrm{~h} \mathrm{~g}{ }^{-1}$. 
a

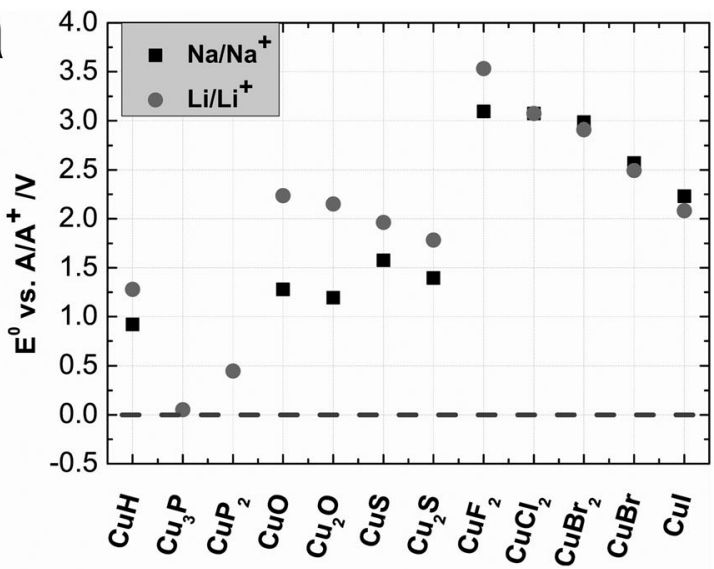

b
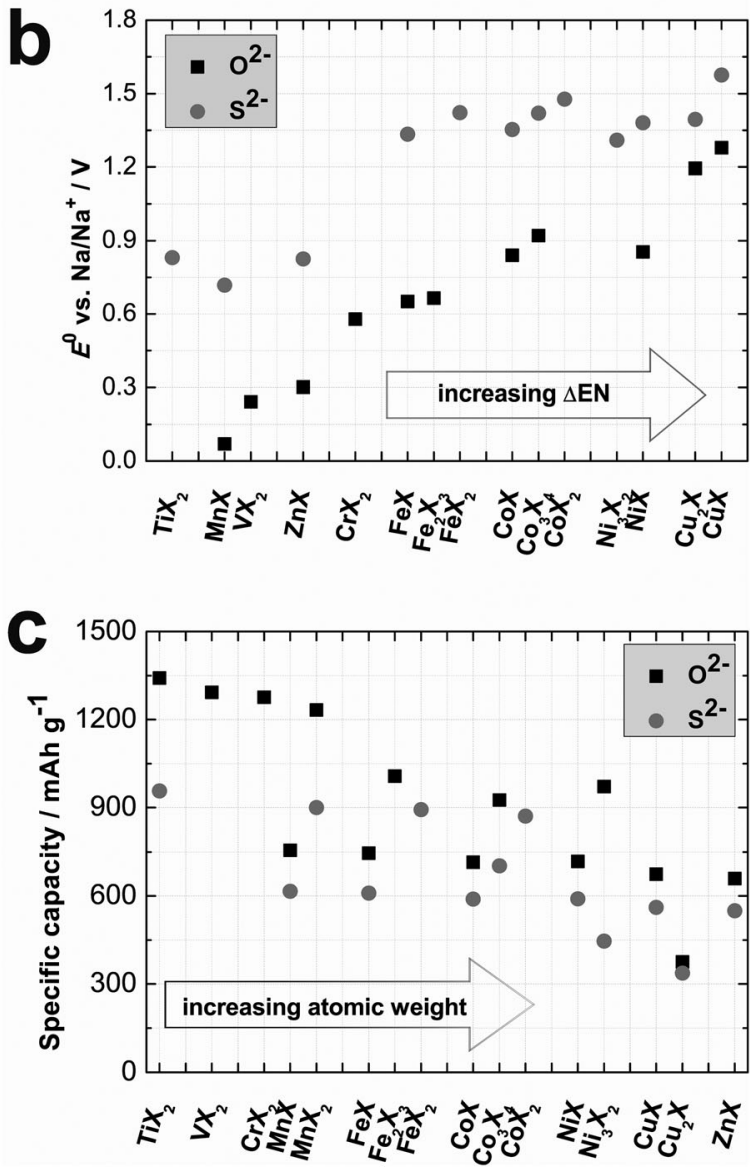

Fig. 2 (a) Standard potential $E^{\circ}$ vs. $\mathrm{Na} / \mathrm{Na}^{+}$and $\mathrm{Li} / \mathrm{Li}^{+}$for different copper compounds. (b) Standard potential $E^{\circ}$ vs. $\mathrm{Na} / \mathrm{Na}^{+}$for different transition metal chalcogenides. The cell potential increases with the difference in electronegativity $\triangle \mathrm{EN}$ (Pauling). Formal conversion of $\mathrm{TiO}_{2}$ with $\mathrm{Na}$ results in a negative cell voltage of $E^{\circ}=-0.35 \mathrm{~V}$. (c) Theoretical specific capacities for different transition metal chalcogenides.

Fig. 3a displays the theoretical cell potential of numerous conversion reactions of sodium with halides. The cell potentials are the highest obtainable ones and reach around $3 \mathrm{~V}$ at maximum for $\mathrm{CuX}_{2}$ compounds. Also here, the specific capacity naturally decreases within the halogen group with the highest values for fluorides (roughly 500-800 $\mathrm{mA} \mathrm{h} \mathrm{g}^{-1}$ ) and chlorides (400-500 $\mathrm{mA} \mathrm{h} \mathrm{g}^{-1}$ ).
An overview of the calculated data is shown in Fig. 4. This map contains the cell voltages and capacities of different classes of materials. The upper limit of the cell potential is given by $\mathrm{CuF}_{2}$ with a theoretical voltage of $3.09 \mathrm{~V}$. This value is little lower compared to what can be obtained for certain layered oxides (e.g. $\mathrm{Na}_{x} \mathrm{MnO}_{2}$ and $\mathrm{Na}_{x} \mathrm{CoO}_{2}$ ) or vanadium fluorophosphates (e.g. $\left.\mathrm{Na}_{3}(\mathrm{VO})_{2}\left(\mathrm{PO}_{4}\right)_{2} \mathrm{~F}\right)$ for which sloping potentials up to $4 \mathrm{~V}$ and reversible intercalation have been already demonstrated. ${ }^{39} \mathrm{How}^{-}$ ever, the theoretical capacities of the last-named compounds, ranging from $100 \mathrm{~mA} \mathrm{~h} \mathrm{~g}{ }^{-1}$ to $150 \mathrm{~mA} \mathrm{~h} \mathrm{~g}{ }^{-1}$, are much smaller compared to that of $\mathrm{CuF}_{2}\left(363 \mathrm{~mA} \mathrm{~h} \mathrm{~g}^{-1}\right.$, including the weight of sodium). Assuming a metallic sodium anode, the theoretical energy densities for conversion reaction with fluorides and chlorides could reach values between 700 and $1100 \mathrm{~W} \mathrm{~h} \mathrm{~kg} \mathrm{~kg}^{-1}$. For comparison, these values are much higher than the theoretical energy densities of currently used Li-ion cathode materials such as $\mathrm{LiFePO}_{4}\left(570 \mathrm{~W} \mathrm{~h} \mathrm{~kg}^{-1}\right)$ or $\mathrm{LiCoO}_{2}\left(550 \mathrm{~W} \mathrm{~h} \mathrm{~kg}^{-1}, 0.5 \mathrm{e}^{-}\right)$ against a lithium anode. For negative electrodes, sulfides, oxides and phosphides could be candidates as their potential is close to that of metallic sodium. In analogy of conversion reactions with lithium, also $\mathrm{MgH}_{2}$ might be an attractive candidate as its potential would be very close to that of metallic sodium $(+0.16 \mathrm{~V})$ and the theoretical capacity reaches $2036 \mathrm{~mA} \mathrm{~h} \mathrm{~g}^{-1}$.

Finally, to sketch out the final limits of sodium based conversion reactions, a cell reaction involving conversion reactions on both electrodes can be imagined. With $\mathrm{MgH}_{2}$ as negative and $\mathrm{CuF}_{2}$ as positive electrode material one could achieve a cell reaction with an gravimetric energy density of $905 \mathrm{Wh} \mathrm{kg}^{-1}$ and a cell potential of $2.93 \mathrm{~V}$, theoretically. The corresponding volumetric energy density for this cell reaction amounts to $2170 \mathrm{Wh}^{-1}$ (charged state).

\section{Volume expansion}

A general challenge for conversion reactions is the relatively large volume change that occurs during cycling that can lead to mechanical degradation of the electrode and hence a poor cycle life. The relative volume change strongly depends on the volume of the active compound $\mathrm{M}_{a} \mathrm{X}_{b}$ and typically ranges for lithium based conversion reactions from 100-200\% (nitrides, phosphides) over $50-150 \%$ (oxides, sulfides) to $15-30 \%$ for the halogens. Among these series, copper compounds generally show the smallest volume changes $\left(12 \%\right.$ for $\mathrm{CuF}_{2}$ and $48 \%$ for $\mathrm{Cu}_{2} \mathrm{~S}$, for example). For comparison, the volume expansions of conventional intercalation materials such as graphite or $\mathrm{LiCoO}_{2}$ are typically below $10 \%$. On the other hand, next generation anode materials based on alloy formation of $\mathrm{Li}$ with $\mathrm{Si}$ or $\mathrm{Sn}$ involve volume changes of a few hundred percent. ${ }^{51} \mathrm{Si}$ and $\mathrm{Sn}$ are known to suffer from very poor cyclability when used as bulk particles, but the cycling stability can be dramatically increased by optimization of the electrode composition ${ }^{52,53}$ or by nanostructuring ${ }^{54}$ and similar methods therefore also apply for conversion reactions. ${ }^{55,56,75}$

For sodium, the problems associated with volume expansion are more severe due to the larger ionic radius that is between $25 \%$ and 55\% larger compared to lithium, depending on the geometry. 

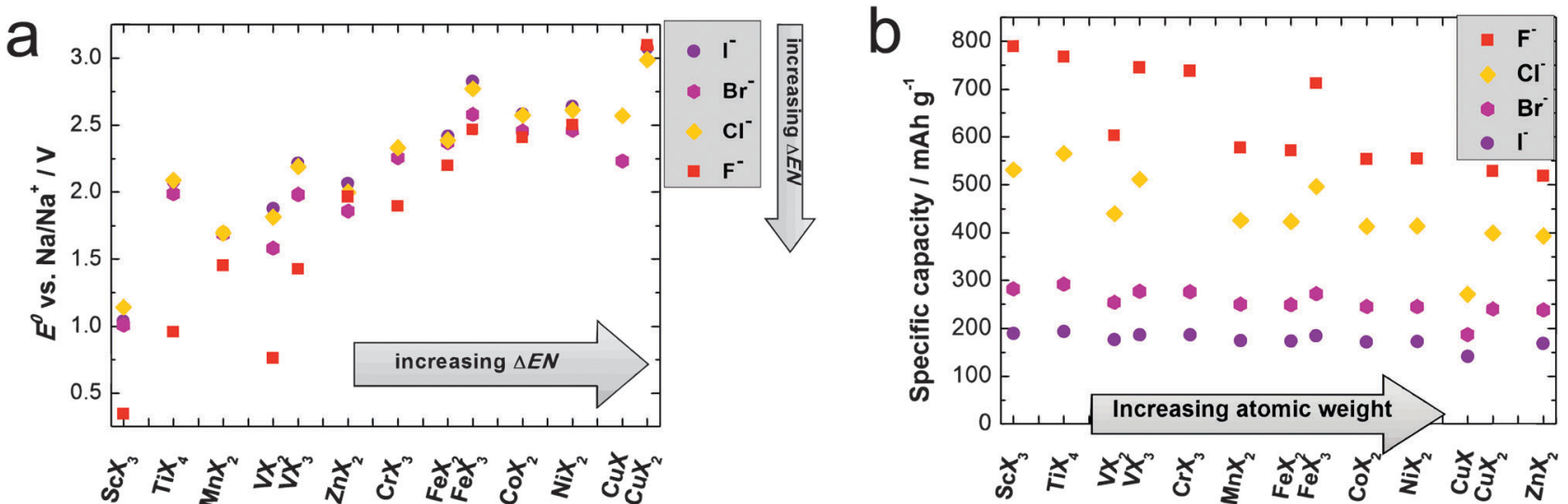

Fig. 3 (a) Standard potential $E^{\circ}$ vs. $\mathrm{Na} / \mathrm{Na}^{+}$for different transition metal halides. (b) Theoretical specific capacities for different transition metal halides.

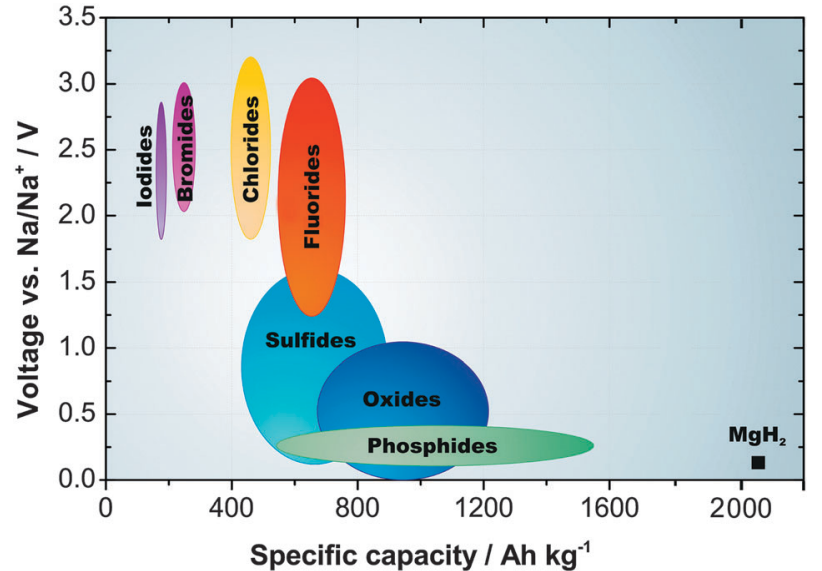

Fig. 4 Specific capacities and cell potentials vs. $\mathrm{Na} / \mathrm{Na}^{+}$for conversion reactions of different classes of materials with sodium.

Table 4 Ionic radii of $\mathrm{Li}^{+}$and $\mathrm{Na}^{+}$for different coordination numbers $(\mathrm{CN})^{57}$

\begin{tabular}{llll}
\hline $\mathrm{CN}$ & $r\left(\mathrm{Li}^{+}\right) / \mathrm{nm}$ & $r\left(\mathrm{Na}^{+}\right) / \mathrm{nm}$ & Radii difference $/ \%$ \\
\hline 4 & 0.073 & 0.113 & +54.8 \\
6 & 0.090 & 0.116 & +28.9 \\
8 & 0.106 & 0.132 & +24.5 \\
\hline
\end{tabular}

Consequently, the reaction products $\mathrm{A}_{c} \mathrm{X}$ are also larger for $\mathrm{A}=\mathrm{Na}$ compared to $\mathrm{A}=\mathrm{Li}$ (Tables 4 and 5). Values for the volume expansions of a series of cell reactions are summarized in Table S2 (ESI $\dagger$ ). The general trend is shown in Fig. 5. A reasonable

Table 5 Molar volumes of the different reaction products $\mathrm{Na}_{\mathrm{C}} \mathrm{X}$ and $\mathrm{Li}_{\mathrm{C}} \mathrm{X}$ for conversion reactions with iodides, bromides, chlorides, fluorides, sulfides, oxides and hydrides

\begin{tabular}{llll}
\hline & $\mathrm{A}=\mathrm{Li}$ & $\mathrm{A}=\mathrm{Na}$ & Volume \\
& $V_{\mathrm{m}} / \mathrm{cm}^{3} \mathrm{~mol}$ & $\begin{array}{l}V_{\mathrm{m}} / \mathrm{cm}^{3} \mathrm{~mol} \\
\text { difference/\% }\end{array}$ & +24.2 \\
\hline $\mathrm{AI}$ & 32.967 & 40.955 & +28.1 \\
$\mathrm{ABr}$ & 25.071 & 32.124 & +31.7 \\
$\mathrm{ACl}$ & 20.500 & 26.994 & +53.4 \\
$\mathrm{AF}$ & 9.844 & 15.104 & +50.1 \\
$\mathrm{~A}_{2} \mathrm{~S}$ & 28.013 & 42.047 & +83.9 \\
$\mathrm{~A}_{2} \mathrm{O}$ & 14.844 & 27.303 & +78.1 \\
$\mathrm{AH}$ & 9.694 & 17.265 &
\end{tabular}

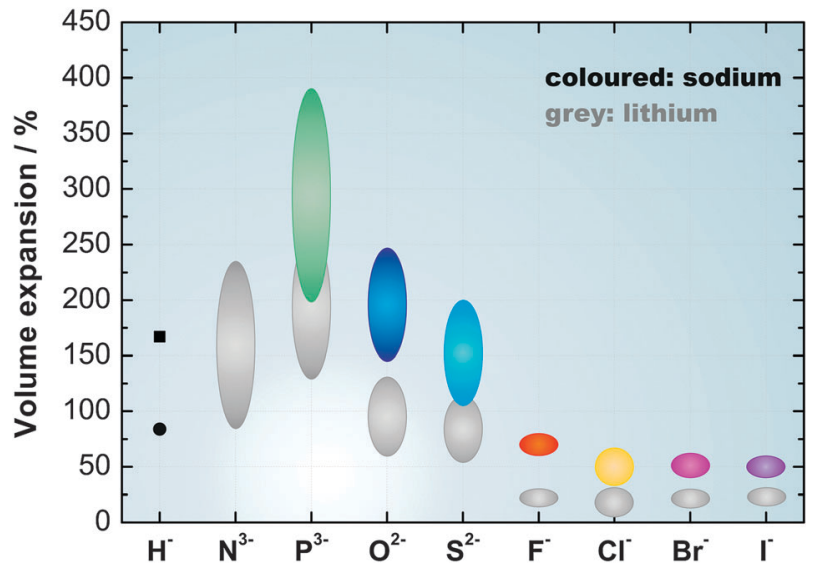

Fig. 5 Calculated volume expansions for lithium and sodium based conversion reactions. Values are calculated as follows: volume expansion $(\%)=100 \cdot\left(\left[V\left(b A_{c} X\right)+\right.\right.$ $\left.V(a \mathrm{M})] / V\left(\mathrm{M}_{a} \mathrm{X}_{b}\right)\right)-100$.

estimation when comparing different conversion reactions is that the relative volume expansion roughly doubles when lithium is substituted by sodium.

\section{Examples on $\mathrm{CuO}, \mathrm{CuS}, \mathrm{CuCl}_{2}$ and $\mathrm{CuCl}$}

In the following, the basic characteristics of a few selected sodium based conversion reactions are being discussed and, where appropriate, compared with the analogue lithium conversion reaction. $\mathrm{CuO}$ and $\mathrm{CuS}$ were chosen, as their conversion with lithium has been relatively well studied and the materials have been applied in primary lithium batteries. ${ }^{18,58} \mathrm{CuCl}$ and $\mathrm{CuCl}_{2}$ were chosen because - as shown above - a negligible difference in cell potential is expected for the conversion reaction with lithium and sodium, respectively. To the best of our knowledge there is no report on conversion reactions of sodium with copper chlorides and CuS available to date.

Also, we note that, besides the fundamental interest in studying the effect of replacing $\mathrm{Li}$ by $\mathrm{Na}$ on the electrochemical properties of the cell reaction, comparative studies between lithium and sodium based conversion reactions might be very 
valuable for two other reasons: firstly, the analysis of sodium compounds is generally easier than the analysis of lithium compounds due to the larger atomic weight of sodium. Studying sodium based conversion reactions might therefore provide easier access to study the cell chemistry. Secondly, it is known that the cycling behavior of conversion electrodes strongly depends on the electrode preparation (type and amount of binders and other additives, weight loading and electrode thickness, for example), the particle size and the morphology of the active material. This is a challenge when studying systematic variations in the electrode composition because two different $\mathbf{M}_{a} \mathbf{X}_{b}$ electrode materials will never exhibit exactly the same particle size, for example, and therefore they never act the same way. In contrast, identical $\mathbf{M}_{a} \mathrm{X}_{b}$ electrodes can be used when studying the effect of the alkali ion on the cell reaction.

Fig. 6 shows the X-ray diffraction patterns of the prepared electrodes before and after discharge and charge. As can be seen, the diffraction lines of the active compounds $\mathrm{CuO}, \mathrm{CuS}$ and $\mathrm{CuCl}$ disappear after discharge, indicating the conversion process. The discharge products $\mathrm{Li}_{2} \mathrm{O}$ and $\mathrm{Li}_{2} \mathrm{~S}$ cannot be identified as they are known to form amorphous or nanocrystalline phases according to the general conversion mechanism as discussed before. For the conversion reaction of $\mathrm{CuO}$ with sodium, some $\mathrm{Cu}_{2} \mathrm{O}$ is found after discharge and charge, indicating an incomplete reaction and only partial reversibility. This finding is in line with what has been reported by Débart et $a .^{23}$ or Martin et $a .^{59}$ for the analogue lithium based conversion reactions and indicates a similar reaction mechanism for both alkali metals. For CuS, also a very broad diffraction line around $39^{\circ}$ appears after discharge. The origin of this reflex is not known but its position is close to NaF that might form as a result of side reactions with the PVDF binder and/or conductive salt as both of them contain fluorine.

Only in the case of $\mathrm{CuCl}$, the theoretical conversion products $\mathrm{NaCl}$ and $\mathrm{Cu}$ are found after discharge by XRD measurements. The sharp diffraction lines show that $\mathrm{NaCl}$ and $\mathrm{Cu}$ are well crystallized. As the behavior of $\mathrm{CuCl}$ is quite different, its electrochemical results will be discussed separately after $\mathrm{CuO}$ and CuS.

\subsection{Results of $\mathrm{CuO}$ and $\mathrm{CuS}$}

The results obtained from galvanostatic cycling of $\mathrm{CuO}$ and $\mathrm{CuS}$ electrodes are shown in Fig. 7. As the cells are cycled down to a potential of $0.01 \mathrm{~V}$ it is important to note beforehand that sodium insertion into the carbon conductive additive can also contribute to some capacity. However the contribution is negligible under the applied conditions as graphite was found inactive towards sodium ion storage and the storage kinetics in non-graphitic carbons ( $\mathrm{CuO}$ and $\mathrm{CuS}$ electrodes contained $15 \mathrm{wt} \%$ SuperPLi as a conductive additive) are generally poor. ${ }^{60}$ For the assayed electrodes, the absolute contribution of carbon to the capacity is around $10 \%$ at maximum (Fig. S2, ESI $\dagger$ ). In general, the behavior is quite similar to what is typical for lithium based conversion reactions, i.e. large overpotentials are found.
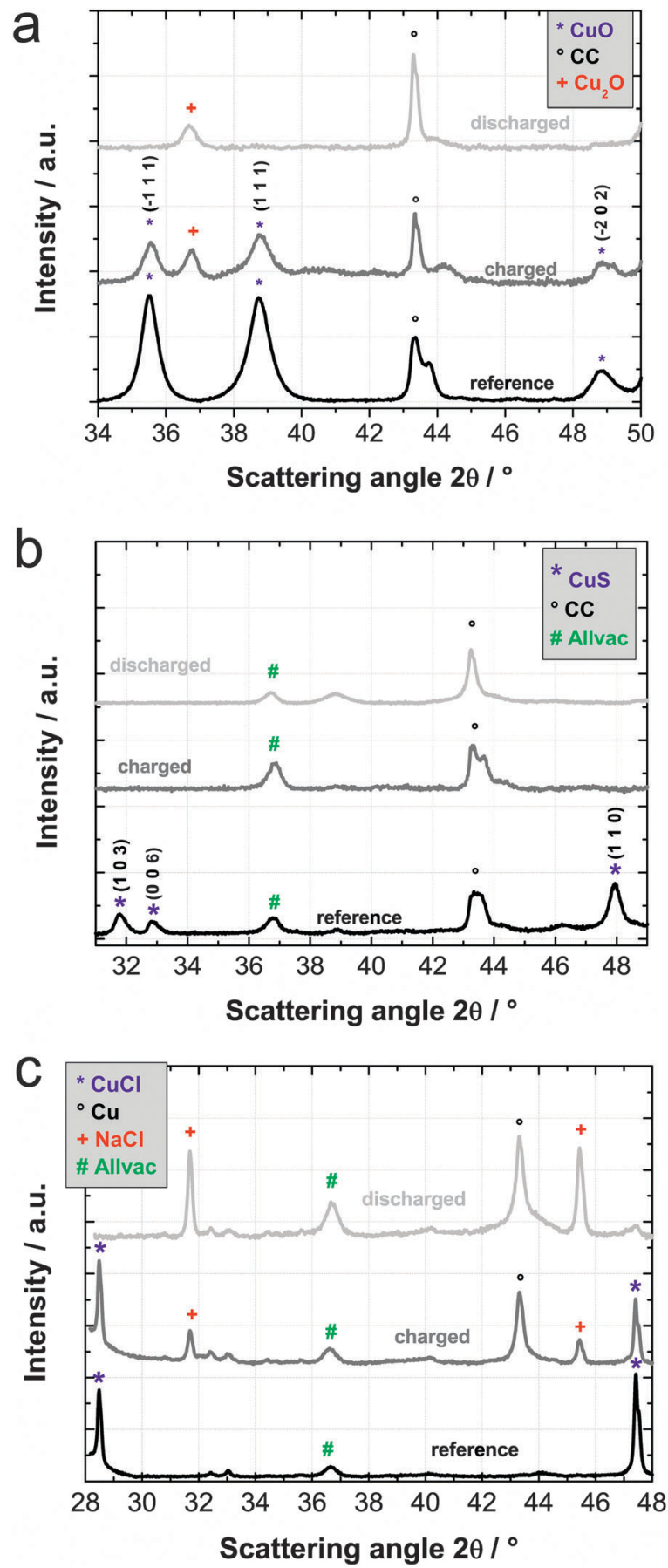

Fig. 6 Diffraction patterns of conversion electrodes before cycling (reference) and after discharge and charge. Allvac denotes the gas barrier foil for measurements under a protective atmosphere. CC denotes the current collector that was used for the $\mathrm{CuO}$ and CuS electrodes; $\mathrm{CuCl}$ electrodes were prepared without a current collector (see Experimental section).

For $\mathrm{CuO}$ (Fig. 7a), the first discharge capacity is slightly lower compared to the theoretical capacity of $674 \mathrm{~mA} \mathrm{~h} \mathrm{~g}^{-1}$. Most of the capacity is gained below $0.6 \mathrm{~V}$ which is around $0.7 \mathrm{~V}$ lower compared to the theoretical value of $E^{\mathrm{O}}=1.28 \mathrm{~V}$. The voltage profile exhibits several steps that might also be related to the formation of intermediate phases such as $\mathrm{Cu}_{2} \mathrm{O}$ and/or 

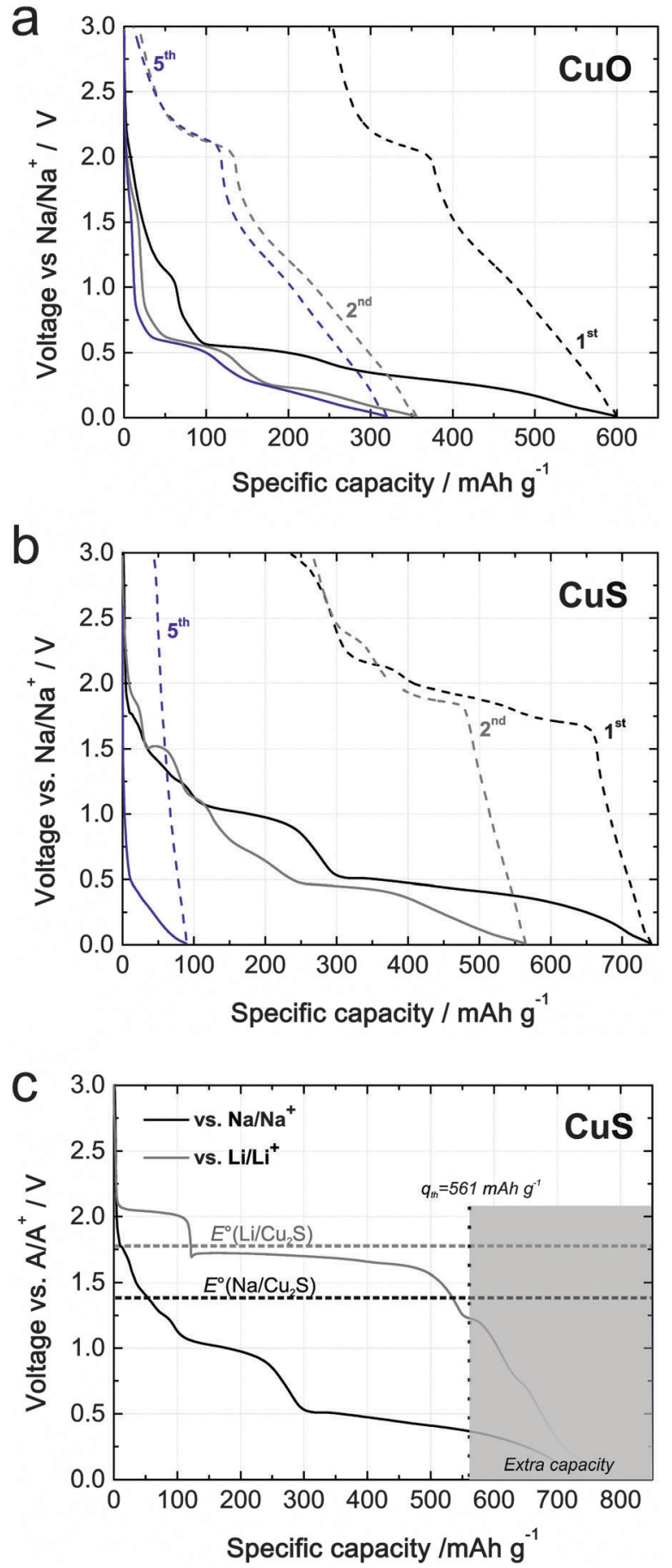

Fig. 7 Results from the galvanostatic cycling of (a) $\mathrm{Na} / \mathrm{CuO}\left(E^{\circ}=1.28 \mathrm{~V}, q_{\mathrm{th}}=\right.$ $\left.674 \mathrm{~mA} \mathrm{~h} \mathrm{~g}^{-1}\right)$ and (b) $\mathrm{Na} / \mathrm{CuS}\left(E^{\circ}=1.58 \mathrm{~V}, q_{\mathrm{th}}=561 \mathrm{~mA} \mathrm{~h} \mathrm{~g}^{-1}\right)$ at $\mathrm{C} / 10$ (c) Comparison of the first galvanostatic discharge curves of $\mathrm{Na} / \mathrm{CuS}$ and $\mathrm{Li} / \mathrm{CuS}$. The dotted lines indicate the theoretical cell potentials for the conversion of $\mathrm{Cu}_{2} \mathrm{~S}$ with $\mathrm{Na}(1.39 \mathrm{~V})$ and $\mathrm{Li}(1.78 \mathrm{~V})$, respectively.

electrolyte instabilities. As discussed above, it is known from the analogue lithium based conversion reaction that the conversion of $\mathrm{CuO}$ is complex and $\mathrm{Cu}_{2} \mathrm{O}$ forms as an intermediate during cycling, which is also electrochemically more reversible (see also ref. 18). Assuming the same intermediate phase in the $\mathrm{Na} / \mathrm{CuO}$ cell, the discharge curve should ideally exhibit two plateaus at $1.36 \mathrm{~V}\left(2 \mathrm{CuO}+2 \mathrm{Na} \rightleftharpoons \mathrm{Na}_{2} \mathrm{O}+\mathrm{Cu}_{2} \mathrm{O}\right)$ and at $1.19 \mathrm{~V}$ $\left(\mathrm{Cu}_{2} \mathrm{O}+2 \mathrm{Na} \rightleftharpoons \mathrm{Na}_{2} \mathrm{O}+2 \mathrm{Cu}\right)$. However differentiation of these steps from the voltage profile is not possible. We note that the conversion of $\mathrm{CuO}$ with lithium and sodium was also compared in the 80 s by Novák et al. In this early and solely electrochemical study, the $\mathrm{Na}-\mathrm{CuO}$ system was found to be much less active compared to the lithium analogue and the lower capacity was mostly related to reaction with the teflonized carbon black additive. Besides the type of carbon additive, also the different electrolyte $\left(\mathrm{NaClO}_{4} /\right.$ propylene carbonate) might explain the observed difference to our results.

For CuS (Fig. 7b), the initial capacity exceeds the theoretical capacity, which can be well understood from the previously discussed phenomenon of extra capacity due to electrolyte decomposition, side reactions including NaF formation, and/ or non-faradaic storage mechanisms. The appearance of two steps in the discharge profile can be related to the observations made for the conversion of CuS with lithium. This reaction is known to proceed in a complex manner due to large variety in the stoichiometry of $\mathrm{Cu}_{2-x} \mathrm{~S}$ at room temperature in an overall two-step mechanism involving the formation of $\mathrm{Cu}_{2} \mathrm{~S}^{61,62}$ Besides, the Li/CuS-cell reaction shows a peculiar behavior that is unique among the lithium based conversion reactions, i.e. very small overpotentials during discharge. Débart et al. explained this finding with the high copper mobility in $\mathrm{Cu}_{2-x} \mathrm{~S}$ and the structural similarity to the $\mathrm{Li}_{2} \mathrm{~S}$ structure. As a result of the latter, the nanoscopic structure typical for conversion reactions is not formed. Instead, a macroscopic phase separation involving the growth of copper dendrites (displacement reaction) is found. ${ }^{63}$ Indeed the molar volumes of $\mathrm{Cu}_{2} \mathrm{~S}$ $\left(28.42 \mathrm{~cm}^{3}\right)$ and $\mathrm{Li}_{2} \mathrm{~S}\left(28.01 \mathrm{~cm}^{3}\right)$ are very similar. For sodium, a similar mechanism is unlikely as the molar volume of $\mathrm{Na}_{2} \mathrm{~S}$ $\left(42.05 \mathrm{~cm}^{3}\right)$ is much larger. Consequently, the overpotentials observed for the present $\mathrm{Na}-\mathrm{CuS}$ system are much larger compared to the analogue Li-CuS system (Fig. 7c) and similar to what is known for conventional conversion systems. A reason for the sloping potential decrease in the case of $\mathrm{Na} / \mathrm{CuS}$ might also be related to the formation of a $\mathrm{Na}_{x} \mathrm{Cu}_{2} \mathrm{~S}$ phase during discharge, as suggested by Kim et al. from experiments on the $\mathrm{Na}-\mathrm{Cu}_{2} \mathrm{~S}$ system. ${ }^{34}$ Also, the overall cycling stability is very poor so far with a drastic capacity decrease upon subsequent cycling for both alkali metals.

\subsection{Results of $\mathrm{CuCl}$ and $\mathrm{CuCl}_{2}$}

For the $\mathrm{CuCl}$ system a defined discharge plateau at $2.5 \mathrm{~V}$ close to the expected voltage of $2.74 \mathrm{~V}$ is found (Fig. 8a) and the discharge ends with a sudden potential drop at $200 \mathrm{~mA} \mathrm{~h} \mathrm{~g}{ }^{-1}$. The reason for this surprisingly low overpotential can be well understood when considering the solubility of the metal chlorides in the electrolyte. Compared to the conventional solid state reaction, the reaction in the dissolved state is kinetically more favored. During cell discharge $\mathrm{NaCl}$ precipitates once the solubility limit is exceeded. As a result, crystalline $\mathrm{NaCl}$ is found in the X-ray diffraction pattern (Fig. 6c). The solubility of the active material certainly demands an alternative cell concept as the chloride species diffuse through the electrolyte towards the sodium anode where they chemically react. Thus, not 

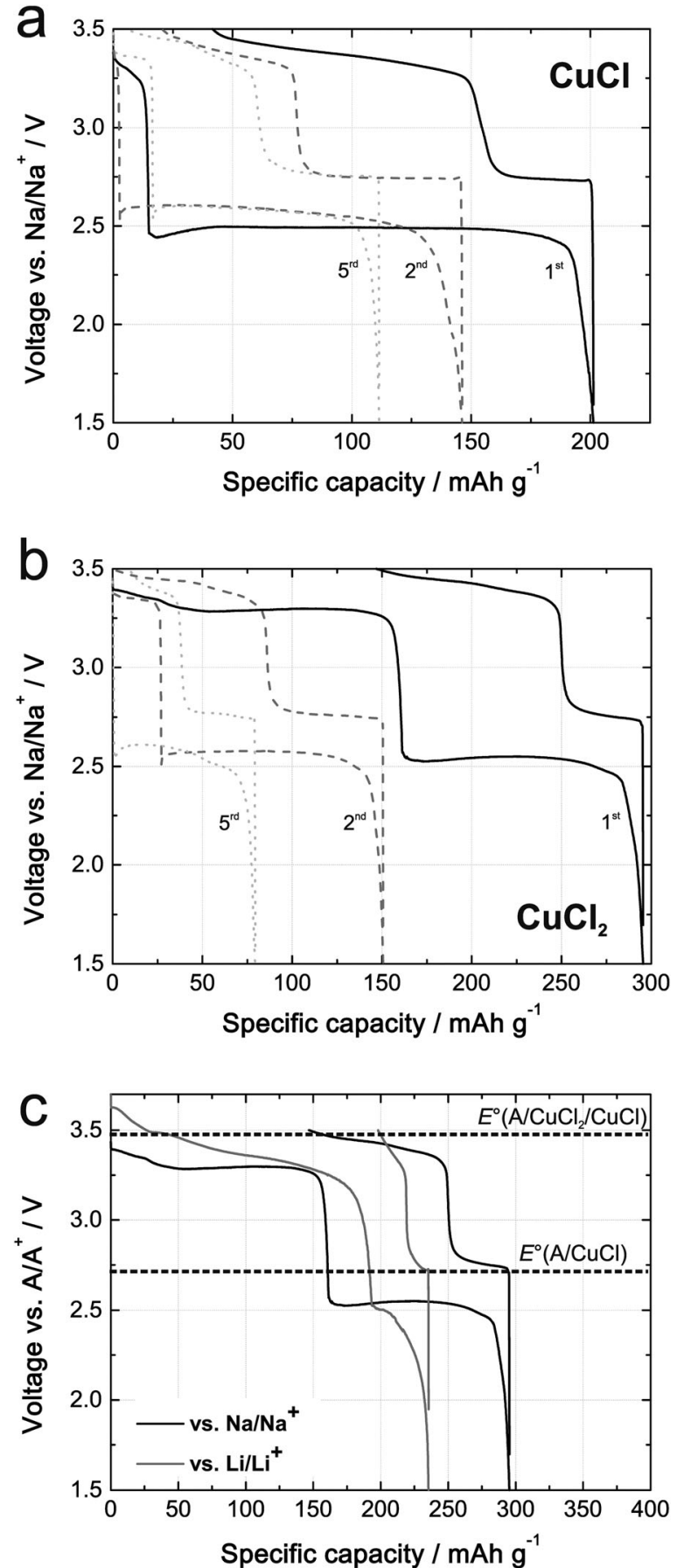

Fig. 8 Galvanostatic cycling at $\mathrm{C} / 10$ of (a) $\mathrm{Na} / \mathrm{CuCl}\left(E^{\circ}=2.74 \mathrm{~V}, q_{\mathrm{th}}=270 \mathrm{~mA} \mathrm{~h} \mathrm{~g}^{-1}\right)$ and (b) $\mathrm{Na} / \mathrm{CuCl}_{2}\left(E^{\circ}=3.07 \mathrm{~V}, q_{\mathrm{th}}=398 \mathrm{~mA} \mathrm{~h} \mathrm{~g}{ }^{-1}\right)$. The two-step conversion of $\mathrm{CuCl}_{2}$ proceeds via the formation of $\mathrm{CuCl}$ as an intermediate. (c) Comparison of the first galvanostatic discharge curves of $\mathrm{Na} / \mathrm{CuCl}_{2}$ and $\mathrm{Li} / \mathrm{CuCl}_{2}$. The dotted lines indicate the theoretical cell potential for the conversion of $\mathrm{CuCl}$ with $\mathrm{Na}$ and $\mathrm{Li}$ at $2.74 \mathrm{~V}(\mathrm{~A}+\mathrm{CuCl} \rightleftharpoons \mathrm{ACl}+\mathrm{Cu})$ and for the intermediate reaction $\mathrm{A}+\mathrm{CuCl}_{2} \rightleftharpoons$ $\mathrm{CuCl}+\mathrm{ACl}$ at $3.41 \mathrm{~V}(\mathrm{~A}=\mathrm{Na}, \mathrm{Li})$.

all $\mathrm{CuCl}$ is converted and the theoretical capacity $\left(270.72 \mathrm{~mA} \mathrm{~h} \mathrm{~g}^{-1}\right)$ is not obtained. We note that similar challenges exist for the lithium-sulfur cell system that suffers from the solubility of polysulfide intermediates, ${ }^{64}$ so that similar concepts to suppress this behavior could be also adapted for the $\mathrm{CuCl}$ system.
During charge, two plateaus at $2.74 \mathrm{~V}$ and between approximately $3.28 \mathrm{~V}$ and $3.44 \mathrm{~V}$ are observed. The second plateau is a result of $\mathrm{CuCl}_{2}$ formation, as can be seen from Fig. 8b. Pure $\mathrm{CuCl}_{2}$ undergoes a two-step conversion reaction with $\mathrm{CuCl}$ as an intermediate during discharge and shows the same plateaus during charging. The formation of the intermediate phase after

$$
\mathrm{CuCl}_{2}+\mathrm{Na} \rightleftarrows \mathrm{CuCl}+\mathrm{NaCl}\left(\Delta_{\mathrm{r}} G^{\mathrm{o}}=-328.71 \mathrm{~kJ} \mathrm{~mol}^{-1}\right)
$$

corresponds to a cell potential of $E^{\mathrm{o}}=3.41 \mathrm{~V}$. Even though this reaction substantially contributes to the capacity gained during charging, its contribution during discharge becomes much smaller during cycling and most of the capacity obtained is close to the potential of $\mathrm{CuCl}$ conversion. This probably means that the formed $\mathrm{CuCl}_{2}$ species chemically react to form $\mathrm{CuCl}$ and $\mathrm{NaCl}$ at the anode side. Consequently, we also only find $\mathrm{CuCl}$ or $\mathrm{NaCl}$ on the cathode after charging (Fig. S3, ESI $\dagger$ ). This detrimental side reaction with the sodium anode might be overcome by using a solid electrolyte that separates both half cells into anode and cathode compartments. We note that corrosion is a general issue when working with chloride solutions and one needs to keep in mind that detrimental side reactions can occur with other cell components such as current collectors and/or binder materials. In order to minimize these effects we chose a thick, free standing carbon membrane as a conductive matrix in which the chlorides were deposited by wet impregnation prior cycling. Fig. $8 \mathrm{c}$ shows a comparison of the conversion reactions of $\mathrm{CuCl}_{2}$ with sodium and lithium under identical conditions. Even though the cell reactions should appear at identical potentials for both alkali metals, it can be seen that the lithium based conversion reaction is surprisingly much less defined compared to sodium. Also, the reversibility of the cell reaction is much poorer in the case of lithium with negligible capacity after 5 cycles (Fig. S4, ESI $†$ ). Here it should be noted that the results for the $\mathrm{Li} / \mathrm{CuCl}_{2}$ cell are somewhat different from what was previously reported for the same cell system by Li et al., ${ }^{65}$ who found an even lesser defined discharge profile but better cycling stability.

\subsection{Additional aspects}

At last, it should be reminded again that though a large amount of research papers has been published on conversion reactions with lithium, only very little is known about the exact underlying mechanisms and intermediate occurring phases. Detailed studies on model electrodes and in situ studies recently provided more insight into the cell chemistry of lithium based conversion reactions. As intriguing examples, Martin et al. ${ }^{59}$ found by XPS measurements an additional ' $\mathrm{Li}_{2} \mathrm{O}_{2}$ ' intermediate phase during conversion of $\mathrm{CuO}$ with lithium. And Wang et al. ${ }^{24,66}$ showed by TEM investigations that a difference in reversibility of $\mathrm{FeF}_{2}$ and $\mathrm{CuF}_{2}$ is probably related to differences in diffusivity. Obviously, applying such methods will also be crucial to clarify the reaction mechanisms of sodium based conversion reactions. When replacing lithium by sodium in conversion reactions, diffusivity and phase stabilities will change and it needs to be elucidated whether these differences result in an improved cell performance or not. As examples, 
lithium only forms the thermodynamically stable sulfide $\mathrm{Li}_{2} \mathrm{~S}^{67}$ and the oxides $\mathrm{Li}_{2} \mathrm{O}$ and $\mathrm{Li}_{2} \mathrm{O}_{2},{ }^{68}$ whereas for sodium, $\mathrm{Na}_{2} \mathrm{~S}$, $\mathrm{Na}_{2} \mathrm{~S}_{2}, \mathrm{Na}_{2} \mathrm{~S}_{4}, \mathrm{Na}_{2} \mathrm{~S}_{5},{ }^{69}$ and $\mathrm{Na}_{2} \mathrm{O}, \mathrm{Na}_{2} \mathrm{O}_{2}$ and $\mathrm{NaO}_{2}{ }^{70}$ are stable at room temperature. As a result of these differences in thermodynamic stabilities, the cell reaction might proceed in an unexpected way. Our results on comparative studies between sodium and lithium based conversion reactions for CuS and $\mathrm{CuCl}$ hence further support the recently renewed interest in sodium based battery systems. Another example for the beneficial impact of intermediate phases on the cell reaction was also recently given by Darwiche et al. ${ }^{71}$ by comparing the alloy formation of $\mathrm{Sb}$ with $\mathrm{Li}$ and $\mathrm{Na}$, respectively.

\section{Conclusion}

Besides the search for suitable intercalation compounds, conversion reactions can be considered as potential electrode materials for sodium-ion batteries. Because numerous cell reactions can be imagined, we discussed the fundamental aspects of conversion reactions for sodium-ion batteries to define their scope and limits based on their basic thermodynamic properties. Capacities, voltages and volume expansions have been summarized for a variety of compounds and were compared with the analogue lithium based conversion reactions. It was shown - for otherwise identical cell reactions - that replacing lithium by sodium leads to a constant shift in cell potential $\Delta E_{(\mathrm{Li}-\mathrm{Na})}^{\mathrm{O}}$ that depends on the nature of the anion. The cell voltages $v s$. $\mathrm{Na} / \mathrm{Na}^{+}$for sodium based conversion reaction are lower for oxides $\left(\Delta E_{(\mathrm{Li}-\mathrm{Na})}^{\mathrm{O}}=0.96 \mathrm{~V}\right)$, fluorides $(0.44 \mathrm{~V})$, sulfides $(0.39 \mathrm{~V})$ and hydrides $(0.36 \mathrm{~V})$. Chlorides show nearly identical cell voltages for conversion reactions with both alkali metals. For the other halides, the cell potential would be even higher in the case of sodium. An identical or even higher cell potential of a sodium cell compared to its lithium analogue is very surprising at first and somewhat counter intuitive but was shown to be a result of the differences in lattice, ionization and sublimation enthalpies (Born-Haber cycles).

The theoretical energy densities of conversion reactions of sodium with fluorides or chlorides as positive electrode materials typically reach values between $700 \mathrm{~W} \mathrm{~h} \mathrm{~kg}^{-1}$ and $1000 \mathrm{~W} \mathrm{~h} \mathrm{~kg}^{-1}$ and are hence much higher compared to commercialized systems for lithium-ion batteries. For solid electrodes, a more severe challenge is the comparable large volume expansion during cell reaction. As a result of the larger ionic radius of the sodium ion, the relative volume expansions are roughly twice as high compared to the lithium analogue. Nevertheless, it can be concluded from the thermodynamic assessment that conversion reactions provide attractive opportunities in the field of sodium-ion batteries but further experimental studies are needed to decide on their practicability.

Our first experimental results on different copper compounds showed that conversion of $\mathrm{CuO}, \mathrm{CuS}$, and $\mathrm{CuCl}_{2}$ with sodium proceeds over intermediate phases as evidenced by XRD and electrochemical measurements. The larger ionic radius of sodium also directly explains why the displacement mechanism known from Li/CuS cells is less likely in the $\mathrm{Na-CuS} \mathrm{system.} \mathrm{Most} \mathrm{importantly,} \mathrm{the} \mathrm{solubility} \mathrm{of} \mathrm{chlorides}$ in the electrolyte gives rise to a conversion reaction at very well defined potentials with only little kinetic limitations. But improved cyclability of this cell system will be probably only feasible with a cell concept including a liquid cathode (catholyte). Such a concept would at the same time also reduce the challenges related to the large volume changes that solid electrodes undergo during cell cycling.

\section{Experimental section}

The electrochemical tests were done with three electrode Swagelok-type cells using $\mathrm{CuO}, \mathrm{CuS}$ (>99\%), $\mathrm{CuCl}(97 \%)$ and $\mathrm{CuCl}_{2}$ (99\%), all received from Sigma Aldrich, as positive electrodes and sodium metal (provided by BASF) and lithium foil (Rockwood Lithium) as negative electrodes, and a borosilicate glass fiber sheet (Whatman, GF/A) as a separator soaked with $1 \mathrm{M} \mathrm{NaPF}_{6}$ (Aldrich, 98\%) in a mixture of dimethyl carbonate (DMC) and ethylene carbonate (EC) electrolyte (w/w $7: 3$ ) (all Sigma Aldrich). The amount of electrolyte solution used in each cell was $95 \mu \mathrm{l}$. All electrodes were circular discs with a diameter of $12 \mathrm{~mm}$.

The positive electrodes $\mathrm{CuO}$ and $\mathrm{CuS}$ were prepared by doctor blading a slurry on copper foil (Schlenk Metallfolien). The slurry contained $65 \mathrm{wt} \%$ of active material, $15 \mathrm{wt} \%$ SFG-44 (Timcal) and $10 \mathrm{wt} \%$ Super PLi (Timcal) as a conductive additive, and $10 \mathrm{wt} \%$ polyvinylidene fluoride (PVDF, Solef 1310, Solvay) as a binder. $N$-Methyl-2-pyrrolidone (NMP) was used as solvent. The total amount of active material on the electrode was between 2 and $5 \mathrm{mg}$ per $\mathrm{cm}^{2}$. $\mathrm{CuCl}$ and $\mathrm{CuCl}_{2}$, dissolved in acetonitrile or ethanol, were spread on a free standing carbon membrane (H2315, Freudenberg) (no binder added). The total amount of active material on the carbon membrane was between 7 and $9 \mathrm{mg}$ per $\mathrm{cm}^{2}$. Electrochemical studies were conducted in a two-electrode arrangement (Swageloktype). Cells were assembled in an argon filled glovebox (GS Glovebox Systemtechnik, $\mathrm{O}_{2}$ and $\mathrm{H}_{2} \mathrm{O}$ levels $<1.5 \mathrm{ppm}$ ) and were cycled galvanostatically at $25{ }^{\circ} \mathrm{C}$ at a current of $\mathrm{C} / 10$ using a Maccor (Serie 4000) battery cycler. The voltage window was $0.01-3.0 \mathrm{~V}$ for $\mathrm{CuO}$ and $\mathrm{CuS}$ and $1.5-4.0 \mathrm{~V}$ for $\mathrm{CuCl}$ and $\mathrm{CuCl}_{2}$. Structural characterizations before, during and after cycling were accomplished by X-ray diffraction (XRD, X'Pert PRO, PANanlytical) with $\mathrm{Cu} \mathrm{K} \alpha$ radiation $(\lambda=1.5406 \AA)$. For analyzing the XRD patterns X'Pert HighScore Plus was used. Unless otherwise stated, all thermodynamic data $(T=298 \mathrm{~K})$ were taken from the database provided in HSC Chemistry 7.0 (Outotec Research).

\section{Acknowledgements}

We thank BASF SE for providing high purity metallic sodium and Jürgen Janek for scientific discussion.

\section{References}

1 C. J. Barnhart and S. M. Benson, Energy Environ. Sci., 2013, 6, 1083-1092.

2 A. S. Arico, P. Bruce, B. Scrosati, J.-M. Tarascon and W. van Schalkwijk, Nat. Mater., 2005, 4, 366-377. 
3 N. S. Choi, Z. H. Chen, S. A. Freunberger, X. L. Ji, Y. K. Sun, K. Amine, G. Yushin, L. F. Nazar, J. Cho and P. G. Bruce, Angew. Chem., Int. Ed., 2012, 51, 9994-10024.

4 J. B. Goodenough and Y. Kim, Chem. Mater., 2010, 22, 587-603.

5 B. L. Ellis, K. T. Lee and L. F. Nazar, Chem. Mater., 2010, 22, 691-714.

6 M. S. Whittingham, Chem. Rev., 2004, 104, 4271-4301.

7 M. M. Thackeray and J. Coetzer, Mater. Res. Bull., 1981, 16, 591-597.

8 G. L. Henriksen and A. N. Jansen, in Linden's Handbook of Batteries, ed. T. B. Reddy, McGraw-Hill, 2001.

9 H. Ikeda and S. Narukawa, J. Power Sources, 1983, 9, 329-334.

10 P. Novák, Electrochim. Acta, 1985, 30, 1687-1692.

11 P. Novák, B. Klápště and P. Podhájecký, J. Power Sources, 1985, 15, 101-108.

12 P. Podhájecký, B. Klápště, P. Novák, J. Mrha, R. Moshtev, V. Manev and A. Nassalevska, J. Power Sources, 1985, 14, 269-275.

13 M. M. Thackeray, S. D. Baker, K. T. Adendorff and J. B. Goodenough, Solid State Ionics, 1985, 17, 175-181.

14 J. P. Gabano, G. Gerbier, J. Jammet and V. Dechenau, J. Electrochem. Soc., 1972, 119, 459-461.

15 Y. Idota, T. Kubota, A. Matsufuji, Y. Maekawa and T. Miyasaka, Science, 1997, 276, 1395-1397.

16 P. Poizot, S. Laruelle, S. Grugeon, L. Dupont and J. M. Tarascon, Nature, 2000, 407, 496-499.

17 R. Malini, U. Uma, T. Sheela, M. Ganesan and N. G. Renganathan, Ionics, 2009, 15, 301-307.

18 J. Cabana, L. Monconduit, D. Larcher and M. R. Palacín, Adv. Mater., 2010, 22, E170-E192.

19 Y. Oumellal, A. Rougier, G. A. Nazri, J. M. Tarascon and L. Aymard, Nat. Mater., 2008, 7, 916-921.

20 H. Li, P. Balaya and J. Maier, J. Electrochem. Soc., 2004, 151, A1878-A1885.

21 F. Wang, R. Robert, N. A. Chernova, N. Pereira, F. Omenya, F. Badway, X. Hua, M. Ruotolo, R. Zhang, L. Wu, V. Volkov, D. Su, B. Key, M. S. Whittingharn, C. P. Grey, G. G. Amatucci, Y. Zhu and J. Graetz, J. Am. Chem. Soc., 2011, 133, 18828-18836.

22 N. Yamakawa, M. Jiang and C. P. Grey, Chem. Mater., 2009, 21, 3162-3176.

23 A. Débart, L. Dupont, P. Poizot, J. B. Leriche and J. M. Tarascon, J. Electrochem. Soc., 2001, 148, A1266-A1274.

24 F. Wang, H.-C. Yu, M.-H. Chen, L. Wu, N. Pereira, K. Thornton, A. Van der Ven, Y. Zhu, G. G. Amatucci and J. Graetz, Nat. Commun., 2012, 3, 1201.

25 A. Ponrouch, P.-L. Taberna, P. Simon and M. R. Palacín, Electrochim. Acta, 2012, 61, 13-18.

26 E. Bekaert, P. Balaya, S. Murugavel, J. Maier and M. Ménétrier, Chem. Mater., 2009, 21, 856-861.

27 P. Balaya, A. J. Bhattacharyya, J. Jamnik, Y. F. Zhukovskii, E. A. Kotomin and J. Maier, J. Power Sources, 2006, 159, 171-178.
28 M. Dolle, P. Poizot, L. Dupont and J. M. Tarascon, Electrochem. Solid-State Lett., 2002, 5, A18-A21.

29 S. Laruelle, S. Grugeon, P. Poizot, M. Dolle, L. Dupont and J. M. Tarascon, J. Electrochem. Soc., 2002, 149, A627-A634.

30 S. Grugeon, S. Laruelle, L. Dupont and J. M. Tarascon, Solid State Sci., 2003, 5, 895-904.

31 R. Dedryvére, S. Laruelle, S. Grugeon, P. Poizot, D. Gonbeau and J. M. Tarascon, Chem. Mater., 2004, 16, 1056-1061.

32 L. Gireaud, S. Grugeon, S. Pilard, P. Guenot, J. M. Tarascon and S. Laruelle, Anal. Chem., 2006, 78, 3688-3698.

33 G. Gachot, S. Grugeon, M. Armand, S. Pilard, P. Guenot, J.-M. Tarascon and S. Laruelle, J. Power Sources, 2008, 178, 409-421.

34 J.-S. Kim, D.-Y. Kim, G.-B. Cho, T.-H. Nam, K.-W. Kim, H.-S. Ryu, J.-H. Ahn and H.-J. Ahn, J. Power Sources, 2009, 189, 864-868.

35 T. B. Kim, J. W. Choi, H. S. Ryu, G. B. Cho, K. W. Kim, J. H. Ahn, K. K. Cho and H. J. Ahn, J. Power Sources, 2007, 174, 1275-1278.

36 R. Alcantara, M. Jaraba, P. Lavela and J. L. Tirado, Chem. Mater., 2002, 14, 2847.

37 Q. Sun, Q. Q. Ren, H. Li and Z. W. Fu, Electrochem. Commun., 2011, 13, 1462-1464.

38 J. S. Kim, H. J. Ahn, H. S. Ryu, D. J. Kim, G. B. Cho, K. W. Kim, T. H. Nam and J. H. Ahn, J. Power Sources, 2008, 178, 852-856.

39 B. L. Ellis and L. F. Nazar, Curr. Opin. Solid State Mater. Sci., 2012, 16, 168-177.

40 S.-W. Kim, D.-H. Seo, X. Ma, G. Ceder and K. Kang, Adv. Eng. Mater., 2012, 2, 710-721.

41 V. Palomares, P. Serras, I. Villaluenga, K. B. Hueso, J. Carretero-Gonzalez and T. Rojo, Energy Environ. Sci., 2012, 5, 5884-5901.

42 M. D. Slater, D. Kim, E. Lee and C. S. Johnson, Adv. Funct. Mater., 2012, 947-958.

43 Q. Sun, Y. Yang and Z.-W. Fu, Electrochem. Commun., 2012, 16, 22-25.

44 P. Hartmann, C. L. Bender, J. Sann, A. K. Durr, M. Jansen, J. Janek and P. Adelhelm, Phys. Chem. Chem. Phys., 2013, 15, 11661-11672.

45 P. Hartmann, C. L. Bender, M. Vracar, A. K. Duerr, A. Garsuch, J. Janek and P. Adelhelm, Nat. Mater., 2013, 12, 228-232.

46 C. W. Park, J. H. Ahn, H. S. Ryu, K. W. Kim and H. J. Ahn, Electrochem. Solid-State Lett., 2006, 9, A123-A125.

47 H. Ryu, T. Kim, K. Kim, J.-H. Ahn, T. Nam, G. Wang and H.-J. Ahn, J. Power Sources, 2011, 196, 5186-5190.

48 S. Wenzel, H. Metelmann, C. Raiß, A. K. Dürr, J. Janek and P. Adelhelm, J. Power Sources, 2013, 243, 758-765.

49 X. Liu, S. Kang, J. Kim, H. Ahn, S. Lim and I. Ahn, Rare Met., 2011, 30, 5-10.

50 X. Li, M. M. Hasan, A. L. Hector and J. R. Owen, J. Mater. Chem. A, 2013, 1, 6441-6445.

51 M. N. Obrovac, L. Christensen, D. B. Le and J. R. Dahn, J. Electrochem. Soc., 2007, 154, A849-A855.

52 G. Liu, S. D. Xun, N. Vukmirovic, X. Y. Song, P. OlaldeVelasco, H. H. Zheng, V. S. Battaglia, L. W. Wang and W. L. Yang, Adv. Mater., 2011, 23, 4679-4683. 
53 I. Kovalenko, B. Zdyrko, A. Magasinski, B. Hertzberg, Z. Milicev, R. Burtovyy, I. Luzinov and G. Yushin, Science, 2011, 333, 75-79.

54 H. Wu and Y. Cui, Nano Today, 2012, 7, 414-429.

55 W. Zaïdi, Y. Oumellal, J. P. Bonnet, J. Zhang, F. Cuevas, M. Latroche, J. L. Bobet and L. Aymard, J. Power Sources, 2011, 196, 2854-2857.

56 J. Li, H. M. Dahn, L. J. Krause, D.-B. Le and J. R. Dahn, J. Electrochem. Soc., 2008, 155, A812-A816.

57 A. F. Holleman and N. Wiberg, Lehrbuch der Anorganischen Chemie, de Gruyter, 2007.

58 T. B. Reddy, R. A. Leising, N. R. Gleason, B. C. Muffoletto and C. F. Holmes, in Linden's Handbook of Batteries, ed. T. B. Reddy, Mc Graw-Hill, 2011.

59 L. Martin, H. Martinez, D. Poinot, B. Pecquenard and F. Le Cras, J. Phys. Chem. C, 2013, 117, 4421-4430.

60 S. Wenzel, T. Hara, J. Janek and P. Adelhelm, Energy Environ. Sci., 2011, 4, 3342-3345.

61 D. J. Chakrabarti and D. E. Laughlin, Bull. Alloy Phase Diagrams, 1983, 4, 254-269.

62 J. S. Chung and H. J. Sohn, J. Power Sources, 2002, 108, 226-231.

63 A. Débart, L. Dupont, R. Patrice and J. M. Tarascon, Solid State Sci., 2006, 8, 640-651.

64 Y. V. Mikhaylik and J. R. Akridge, J. Electrochem. Soc., 2004, 151, A1969-A1976.
65 T. Li, Z. X. Chen, Y. L. Cao, X. P. Ai and H. X. Yang, Electrochim. Acta, 2012, 68, 202-205.

66 F. Wang, R. Robert, N. A. Chernova, N. Pereira, F. Omenya, F. Badway, X. Hua, M. Ruotolo, R. G. Zhang, L. J. Wu, V. Volkov, D. Su, B. Key, M. S. Whittingharn, C. P. Grey, G. G. Amatucci, Y. M. Zhu and J. Graetz, J. Am. Chem. Soc., 2011, 133, 18828-18836.

67 H. Okamoto, J. Phase Equilib., 1995, 16, 94-97.

68 J. Sangster and A. D. Pelton, J. Phase Equilib., 1992, 13, 296-299.

69 J. Sangster and A. D. Pelton, J. Phase Equilib., 1997, 18, 89-96.

70 H. A. Wriedt, Bull. Alloy Phase Diagrams, 1987, 8.

71 A. Darwiche, C. Marino, M. T. Sougrati, B. Fraisse, L. Stievano and L. Monconduit, J. Am. Chem. Soc., 2012, 134, 20805-20811.

72 S. Hariharan, K. Saravanan, V. Ramar and P. Balaya, Phys. Chem. Chem. Phys., 2013, 15, 2945-2953.

73 J.-L. Yue, Q. Sun and Z.-W. Fu, Chem. Commun., 2013, 49, 5868-5870.

74 H. D. B. Jenkins and H. K. Roobottom, CRC Handbook of Chemistry and Physics, 85th edn, 2004-2005. Section 12: Properties of Solids (12-22 to 12-30), Table 1: lattice energies.

75 C. Erk, T. Brezesinski, H. Sommer, R. Schneider and J. Janek, ACS Appl. Mater. Interfaces, DOI: 10.1021/am401642c. 